\title{
Nutrient Response Functions of Sorghum for Miesso District Central Rift Valley of Ethiopia
}

\author{
Israel Bekele, Mesfin Hundessa, Bahiru Tilahun \\ Ethiopian Institute of Agricultural Research (EIAR), Melkassa Agricultural Research Center (MARC), \\ Melkassa, Ethiopia \\ Email: 2012israelb@gimail.com
}

How to cite this paper: Bekele, I., Hundessa, M. and Tilahun, B. (2022) Nutrient Response Functions of Sorghum for Miesso District Central Rift Valley of Ethiopia. Agricultural Sciences, 13, 33-48. https://doi.org/10.4236/as.2022.131004

Received: October 26, 2021

Accepted: January 22, 2022

Published: January 25, 2022

Copyright (c) 2022 by author(s) and Scientific Research Publishing Inc. This work is licensed under the Creative Commons Attribution International License (CC BY 4.0). http://creativecommons.org/licenses/by/4.0/

Open Access

\begin{abstract}
This study was executed to offer the basis for optimized profit from fertilizer use for sorghum yield and to determine robust crop nutrient response function and economic rate for the production of sorghum at Miesso Central Rift Valley of Ethiopia. Trails were conducted at six experimental sites, sorghum yield response to $\mathrm{N}$ and $\mathrm{P}$ fertilizers application and economically optimum rates of nitrogen (EONR) and phosphorus (EOPR) were evaluated on a vertisols within the semi-arid Miesso districts west Hararge zone of Oromia region. The nutrient rates in 2014 cropping season four levels of Nitrogen $(\mathrm{N})$ alone, these levels with $20 \mathrm{~kg} \cdot \mathrm{ha}^{-1}$ Phosphorus (P) and without N, $69 \mathrm{~kg} \cdot \mathrm{ha}^{-1}$ $\mathrm{N}$ with three levels of $\mathrm{P}$ treatments including the zero control were evaluated. In 2015, cropping season similar rates of $\mathrm{N}$ alone, the same rate $\mathrm{N}$ with 20 $\mathrm{kg} \cdot \mathrm{ha}^{-1} \mathrm{P}, 92 \mathrm{~kg} \cdot \mathrm{ha}^{-1} \mathrm{~N}$ with three rates of $\mathrm{P}$ including the zero control were evaluated. The treatments were arranged in a randomized complete block with three replications in factorial design. Nutrient responses of sorghum were determined using asymptotic quadratic plateau functions. The significantly highest nitrogen rate was $46 \mathrm{~kg} \cdot \mathrm{ha}^{-1}$ alone in 2014 season, which gave grain yield of $2.56 \mathrm{Mg} \cdot \mathrm{ha}^{-1}$ with a maximum yield advantage of $43 \%$. P rates in both seasons and combined (sites + seasons) were not significantly influenced sorghum yield. Nitrogen agronomic and partial factor productivity peaked at $23 \mathrm{~kg} \mathrm{~N} \mathrm{ha}^{-1}$ but declined with increasing $\mathrm{N}$ rate. The EONR combined (sites + seasons) were 37, 45, 52 and $60 \mathrm{~kg} \cdot \mathrm{ha}^{-1}$ and for the profit to cost ratio (PCR) were $2.43,3.65,4.86$ and 5.79 at difference cost to grain price ratios $(\mathrm{CP})=3.6,2.3,1.6$ and 1.2 respectively at Miesso Ethiopia. Nitrogen application had economically profitable than $\mathrm{P}$. The study concluded that the application of $\mathrm{N}$ at 37 or $60 \mathrm{~kg} \mathrm{~N} \mathrm{ha}^{-1}$ to sorghum production could be economically profitable for those economically constrained farmers or economically not constrained farmers. Validation should be farther conducted on farmers' fields for refining the results obtained.
\end{abstract}




\section{Keywords}

Sorghum, Response Function, Economically Optimum Rates, Nutrient Use Efficiency, Cost to Grain Price Ratio, Ethiopia

\section{Introduction}

Cereals are the major food crops in Ethiopia both in terms of the area they are covered and amount of production obtained. They are produced in larger amount compared with other crops, because they are the major staple crops. Out of the total grain crop area, $79.38 \%$ was under cereals. Teff, maize, sorghum and wheat took up $24.31 \%, 16.08 \%, 13.52 \%$ and $12.94 \%$ of the grain crop area, respectively [1]. Among these sorghum was the third cereal produced in 2013/2014 cropping season. According to the CSA [1] report, the average grain yield of sorghum was $2465 \mathrm{~kg} \cdot \mathrm{ha}^{-1}$.

Low mineral fertilizers use by smallholder farmers in developing countries commonly limits agricultural productivity. Most of farmers in this region do not have the budget to buy enough fertilizer to increase net benefit on their small investment per hectare. High mineral fertilizer costs and low market prices for agricultural production often reduce profit potential. Competing needs for money often take priority. Such farmers need high net returns on their investments to justify the application of fertilizers. Recommendations for non-finance constrained fertilizer use commonly strive to maximize mean net returns across all planted areas. These recommendations are infeasible for smallholders with limited financial capacities. Increasing net benefit needs the fertilizer investments focus on crop nutrient with the highest marginal returns until the budgeted financial resources are exhausted [2].

The economic consequences of soil fertility depletion are great with reduced farm production and food security. Also fertilizer use in Sub Sahara Africa (SSA) countries is low, partly because farmers do not recognize adequate profit opportunity with acceptable risk [3].

Optimization of fertilizer use by smallholders refers the maximization of net returns on the farmers' investment achieved through the best choice of cropnutrient-rate combinations. Making decisions on choice of crop to fertilize and the amount of each nutrient to apply, however, is very complex. Crop responses to applied nutrients needs to be considered in addition to the farmer's land allocation to different crops, the value of the production, the costs of fertilizer use and the money available for fertilizer use [4].

For the other related and above mentioned constraints, the activity of Nutrient response functions of Sorghum and Nitrogen use efficiency was conducted at Miesso district of west Harerghe zone, Oromia Region. Therefore, this study was executed to offer the basis for optimized profit from fertilizer use for sorghum yield and to determine robust crop nutrient response function and economic 
rate for the production of sorghum at Miesso Central Rift Valley of Ethiopia.

\section{Materials and Method}

\subsection{Study Area Description and Rainfall}

Three on farm trials per season were conducted in two consecutive cropping seasons 2014 and 2015 G.C at Miesso district west Harerghe, Oromia region, the geographical locations of the study areas are $09^{\circ} 13^{\prime} 35^{\prime \prime}$ Nothing, $40^{\circ} 45^{\prime} 10^{\prime \prime}$ Easting 1339 masl, 09 $13^{\prime} 8.2^{\prime \prime}$ Northing, 40 45'30" Easting with 1327 masl and $09^{\circ} 13^{\prime} 32^{\prime \prime}$ Northing, $40^{\circ} 45^{\prime} 23^{\prime \prime}$ Easting with the 1338 masl (Figure 1).

At Miasso rainfall distribution is bimodal. The Rainfall data for the 2014 were greater than the 2015 season as indicated in Table 1.

\subsection{Materials}

Twelve treatments were arranged in randomized complete block replicated three times in factorial design. In 2014 and 2015 cropping seasons the treatments arranged in the following table (Table 2).

The sources of $\mathrm{N}$ and $\mathrm{P}$ were urea and triple supper phosphate (TSP). Urea was applied in split, half at planting and the rest top-dressed at knee height. TSP was placed at planting in basal. Sorghum variety ESH-3 at the rate of $12 \mathrm{~kg} \cdot \mathrm{ha}^{-1}$ was planted in rows. Plot size was $4.00 \mathrm{~m}$ by $3.75 \mathrm{~m}$ ( 5 rows) and 3 harvestable

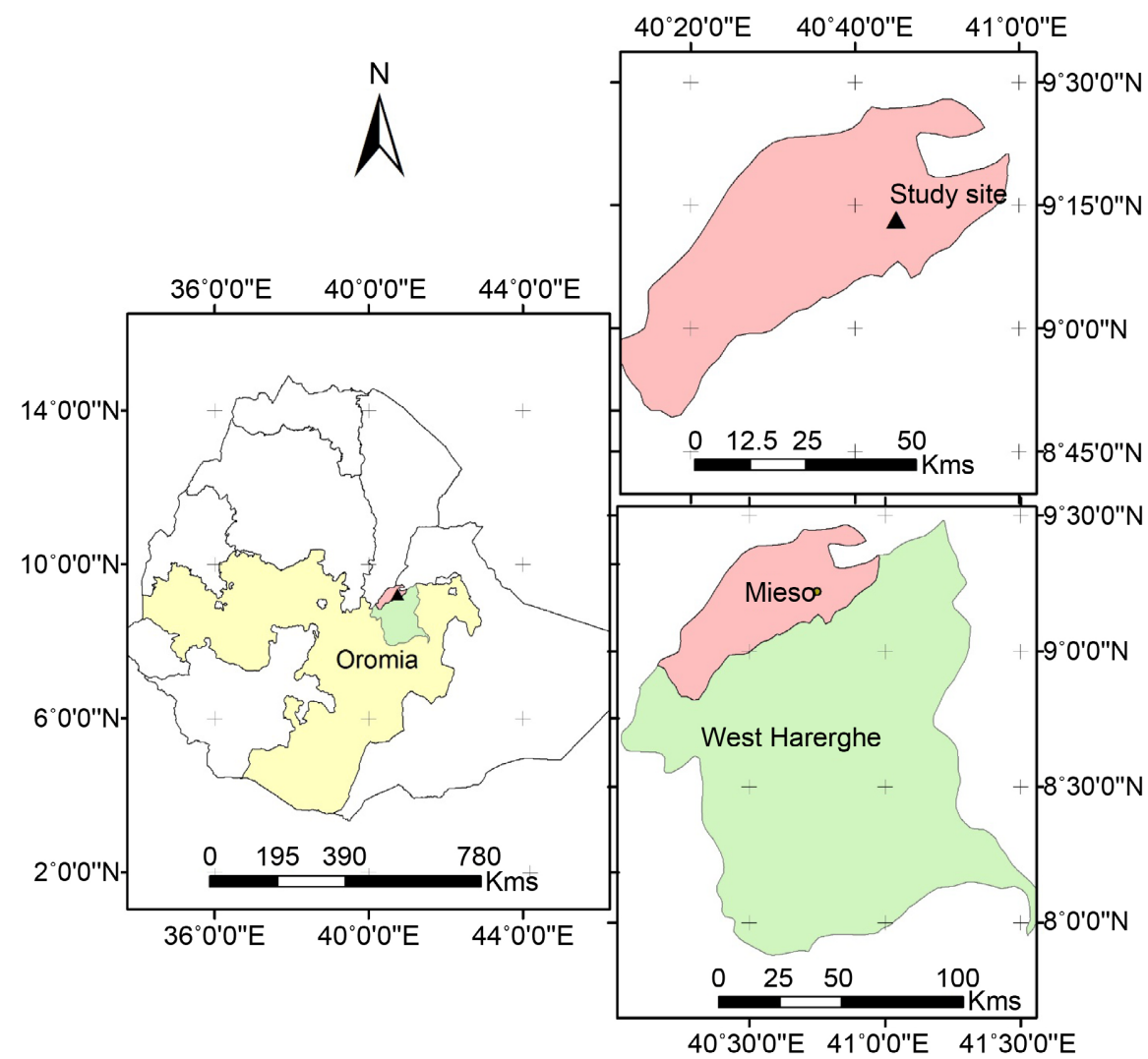

Figure 1. Map of the study site. 
Table 1. Rainfall $(\mathrm{mm})$ and temperature $\left({ }^{\circ} \mathrm{C}\right)$ data of Measo.

\begin{tabular}{cccc}
\hline Year & Rainfall $(\mathrm{mm})$ & Max Temp $\left({ }^{\circ} \mathrm{C}\right)$ & Min Temp $\left({ }^{\circ} \mathrm{C}\right)$ \\
\hline 2014 & 498.6 & 31.1 & 15.0 \\
2015 & 424.8 & 32.1 & 15.5 \\
\hline \multirow{3}{*}{ Main (Meher) season } & Minor (Belg) season \\
2014 & Late Jun-Early Oct & \multicolumn{2}{c}{ Mar-May 15 } \\
2015 & $390 \mathrm{~mm}$ & \multicolumn{2}{c}{$108.6 \mathrm{~mm}$} \\
\hline
\end{tabular}

Table 2. Treatment arrangements in 2014 and 2015 cropping seasons.

\begin{tabular}{ccc}
\hline Treatment & 2014 & 2015 \\
\cline { 2 - 3 } 1 & & $\mathrm{~kg} \cdot \mathrm{ha}^{-1}$ \\
\hline 2 & $0 \mathrm{~N}, 0 \mathrm{P}$ & $0 \mathrm{~N}, 0 \mathrm{P}$ \\
3 & $23 \mathrm{~N}, 0 \mathrm{P}$ & $23 \mathrm{~N}, 0 \mathrm{P}$ \\
4 & $46 \mathrm{~N}, 0 \mathrm{P}$ & $46 \mathrm{~N}, 0 \mathrm{P}$ \\
5 & $69 \mathrm{~N}, 0 \mathrm{P}$ & $69 \mathrm{~N}, 0 \mathrm{P}$ \\
6 & $92 \mathrm{~N}, 0 \mathrm{P}$ & $92 \mathrm{~N}, 0 \mathrm{P}$ \\
7 & $0 \mathrm{~N}, 20 \mathrm{P}$ & $0 \mathrm{~N}, 20 \mathrm{P}$ \\
8 & $23 \mathrm{~N}, 20 \mathrm{P}$ & $23 \mathrm{~N}, 20 \mathrm{P}$ \\
9 & $46 \mathrm{~N}, 20 \mathrm{P}$ & $46 \mathrm{~N}, 20 \mathrm{P}$ \\
10 & $69 \mathrm{~N}, 20 \mathrm{P}$ & $69 \mathrm{~N}, 20 \mathrm{P}$ \\
11 & $92 \mathrm{~N}, 20 \mathrm{P}$ & $92 \mathrm{~N}, 20 \mathrm{P}$ \\
12 & $69 \mathrm{~N}, 10 \mathrm{P}$ & $92 \mathrm{~N}, 10 \mathrm{P}$ \\
& $69 \mathrm{~N}, 30 \mathrm{P}$ & $92 \mathrm{~N}, 30 \mathrm{P}$ \\
\hline
\end{tabular}

rows, $0.75 \mathrm{~m}$ between rows and $0.20 \mathrm{~m}$ between plants.

\subsection{Method}

Following the standard soil sampling procedures, five representative sub-samples from each farmer field was taken at a depth of $0-20 \mathrm{~cm}$ before planting and made one composite sample. Then the samples were labeled and transported to Melkassa Agricultural research Center (MARC) soil laboratory.

At agronomic maturity, sorghum plants within the three central rows of each plot in a net plot area of $9.0 \mathrm{~m}^{2}$ were harvested for Aboveground Biomass (AGB) Grain Yield (GY) determination. Sorghum grains were adjusted to $12.5 \%$ moisture content.

\subsubsection{Laboratory Analysis}

The soil samples were air-dried, crushed with mortar and pestle, passed through $2 \mathrm{~mm}$ wire sieve for various physico-chemical parameters analysis. Soil texture, 
bulk density, $\mathrm{pH}, \mathrm{EC}$, total nitrogen, available phosphorus and organic carbon were determined at Melkassa Agricultural Research Center (MARC) soil laboratory. Other chemical parameters of soil including Exchangeable cations (K, Na, $\mathrm{Ca}, \mathrm{Mg}$ ), Cation exchange capacity (CEC), and Zinc $(\mathrm{Zn})$, Copper $(\mathrm{Cu})$, Iron $(\mathrm{Fe})$ and Manganese $(\mathrm{Mn})$ were determined at Debrezeyit Agricultural Research Center soil laboratory.

Particle size distribution of the soil samples was determined by hydrometer method [5]. Soil bulk density was determined by the undisturbed core sampling method after drying the soil samples in an oven at $105^{\circ} \mathrm{C}$ to constant weights.

Potentiometric method using a glass calomel combination electrode was used to measure $\mathrm{pH}$ of the soils in water suspension in a 1:2.5 (soil: water ratio) [6]. Electrical conductivity (EC) was measured using a conductivity meter from the same soil water suspension extract. The [7] wet digestion method was used to determine soil organic carbon (OC) content. Total nitrogen content of the soil was determined by wet-oxidation procedure of the Kjeldahl method [8]. Available $\mathrm{P}$ was determined using the standard [9] extraction methods. The absorbance of available $\mathrm{P}$ extracted was measured using spectrophotometer after colour development. Exchangeable cations ( $\mathrm{Ca}, \mathrm{Mg}$, $\mathrm{K}$ and $\mathrm{Na}$ ) were determined after extracting the soil samples by $1 \mathrm{~N}$ neutral ammonium acetate $\left(1 \mathrm{~N} \mathrm{NH}_{4} \mathrm{OAc}\right)$ solution adjusted to a $\mathrm{pH}$ 7.0. Exchangeable $\mathrm{Ca}$ and $\mathrm{Mg}$ in the extract were measured by atomic absorption spectrophotometer (AAS) whilst $\mathrm{K}$ and $\mathrm{Na}$ were determined using flame photometer from the same extract [10]. Cation exchange capacity of the soils was determined from the ammonium acetate saturated samples through distillation and measurement of ammonium using the modified Kjeldhal procedure as described by [10]. Micronutrients ( $\mathrm{Fe}, \mathrm{Mn}, \mathrm{Zn}, \mathrm{Cu}$ ) were extracted by Di-ethyl Tri-amine Penta-acetic acid (DTPA) as described by [11] and all these micronutrients were measured by AAS.

The values reported by FAO [12], Jones [13], Clements and McGowen [14], Bruce [15], Tekalign [16], Hazelton and Murphy [17], Landon [18] were used as soil analysis result guide for diagnosing nutrient status of the soil in the test sites.

\subsubsection{Data Collection and Analysis}

Two economically valuable parameters, AGB and GY of sorghum were measured and considered in this analysis. A linear modeling framework was used to determine variation in yield with the different levels of $\mathrm{N}$ and $\mathrm{P}$ by combining study sites and combining study sites and seasons. The linear modeling framework (in PROC LINEAR of the SAS system) was chosen for the different levels of analyses. The model was the following form:

$$
Y=\mu+\text { Season }+ \text { rate }+ \text { Season } * \text { rate }+ \text { Site }+\varepsilon
$$

where $\mu$ is the grand mean yield $\left(\mathrm{Mg} \cdot \mathrm{ha}^{-1}\right)$, season, rate is the rate of application $\left(\mathrm{kg} \cdot \mathrm{ha}^{-1}\right)$ for the nutrient under study, site is the random component and $\varepsilon$ is the error term.

The variations in yield with fixed effects were considered significant when $\mathrm{P} \leq$ 
0.05. Least square estimates and their $95 \%$ confidence intervals were used for statistical inference. The means for two or more levels of a fixed effect were considered to be significantly different from one another only if their 95\% CI were non-overlapping.

In order to determine the optimum rate of the nutrient in question, nutrient response functions were compared and used as deemed appropriate.

When significant nutrient rate effects occurred, the asymptotic quadratic-plateau grain yield response function was fitted to nutrient rates. This function gave an exponential rise to maximum yield or to a yield plateau. The asymptotic function was adjusted grain yield (AGY) $\left(\mathrm{Mg} \cdot \mathrm{ha}^{-1}\right)$.

$$
\mathrm{AGY}=a-b c^{N}
$$

where $a$ is yield at the plateau or maximum yield, $b$ is the gain yield obtained due to nutrient application, and $c^{N}$ determined the shape of the quadratic response, where $c$ is a curvature coefficient and $N$ is the nutrient rate.

Statistical analyses were done by site-season and combined across site-seasons using SAS 9.0 computer program [19] and Statistix 10 (Analytical Software, Tallahassee, FL). The ANOVAs and regression analyses for $\mathrm{N}$ rate effects included treatments with and without $\mathrm{P}$ applied, but a separate yield response analysis combined across site-seasons was done for $\mathrm{N}$ response with no $\mathrm{P}$ applied. Similarly, the ANOVAs for $\mathrm{P}$ rate effects included treatments with and without $\mathrm{N}$ applied. There were no grain yield increases due to applied P. Differences and relationships were considered significant at the $5 \%$ level of probability [20].

In the second step of analyses, we focused on the assessment of the agronomic efficiency of $\mathrm{N}$ (AEN) because this measure production efficiency. AEN also answer a more direct question [21] "How much productivity improvement was gained by the use of this nutrient input". Therefore, AEN is more important for decision-making concerning fertilizer use. The PFPN is an aggregate efficiency index that includes contributions to crop yield derived from uptake of indigenous soil $\mathrm{N}, \mathrm{N}$ fertilizer uptake efficiency, and the efficiency with which $\mathrm{N}$ acquired by the plant is converted to grain yield. AEN and NPFP (nitrogen partial factor productivity) were determined using the formulae following Dobermann [22]:

$$
\begin{gathered}
\operatorname{AEN}\left(\mathrm{kg} \cdot \mathrm{kg}^{-1}\right)=\frac{(\mathrm{YNf}-\mathrm{YN} 0)}{\mathrm{Nr}} \\
\operatorname{NPFP}\left(\mathrm{kg} \cdot \mathrm{kg}^{-1}\right)=\frac{(\mathrm{YNf})}{\mathrm{Nr}}
\end{gathered}
$$

where YNf is the grain yield of the fertilized plot (kg), YN0 is the grain yield of the unfertilized plot $(\mathrm{kg})$ for each replicate, and $\mathrm{Nr}$ is the quantity of $\mathrm{N}$ fertilizer applied (kg).

Economically optimal nutrient rates (EORs) and Net returns to fertilizer use were determined using the OFRA/FOT (fertilizer optimization tool) developed by University of Nebraska. These were dependent on the grain yield, grain value (US\$0.23 kg-1) and farm gate fertilizer (urea) value (US\$1.03 $\mathrm{kg}^{-1}$ ) in 2015 . Non- 
linear regression analysis was also used to derive an equation to relate EONR to a different rate of fertilizer use cost to grain price ratios $(\mathrm{CP})$. The EONR was determined at $\mathrm{CP}$ ratios of $1.2,1.6,2.3$, and 3.6, with $\mathrm{CP}$ as the independent variable.

\section{Result and Discussion}

\subsection{Soil Physicochemical Properties before Planting}

The soil of the experimental site has medium bulk density, very low in salt content and slightly alkaline in reaction, adequate in available phosphorus with low total nitrogen and optimum organic carbon content. All exchangeable bases except sodium were high with high cation exchange capacity (CEC) and base saturation as the standard given by [12]. All micronutrients except zinc were low in these experimental sites as the standard given by [13] Table 3 .

Table 3. Soil physicochemical properties and their standard value of Miesso site.

\begin{tabular}{|c|c|c|c|c|}
\hline Location & & Miesso & Rate & Source \\
\hline Depth & $\mathrm{cm}$ & $0-20$ & & \\
\hline Sand & & 550 & & \\
\hline Clay & $\mathrm{g} \cdot \mathrm{kg}^{-1}$ & 180 & & \\
\hline Silt & & 270 & & \\
\hline T. Class & & SL & & \\
\hline $\mathrm{BD}$ & $\mathrm{g} / \mathrm{cm}^{3}$ & 1.25 & & \\
\hline $\mathrm{pH}$ & & 7.82 & Slightly Alkaline & [13] \\
\hline EC & $\mathrm{dS} / \mathrm{m}$ & 0.59 & V. Low & [13] \\
\hline AP & ppm & 17.2 & Adequate & [14] \\
\hline $\mathrm{TN}$ & g. $\mathrm{kg}^{-1}$ & 1.5 & Low & [15] \\
\hline OC & & 29.2 & Medium & [16] \\
\hline $\mathrm{Na}$ & & 0.56 & V. low & [12] \\
\hline K & & 1.10 & High & [12] \\
\hline $\mathrm{Ca}$ & $\mathrm{Cmol}(+) / \mathrm{kg}$ & 19.63 & High & [12] \\
\hline $\mathrm{Mg}$ & & 8.38 & High & [12] \\
\hline $\mathrm{CEC}$ & & 34.00 & High & [17] \\
\hline BS & $\%$ & 87.24 & High & [18] \\
\hline $\mathrm{Cu}$ & & 0.24 & Low & [13] \\
\hline $\mathrm{Fe}$ & & 1.59 & Low & [13] \\
\hline $\mathrm{Mn}$ & ppm & 4.22 & Low & [13] \\
\hline $\mathrm{Zn}$ & & 4.56 & High & [13] \\
\hline
\end{tabular}




\subsection{Yield Parameters}

The result of 2014 and 2015 cropping seasons and combined analysis (sites + seasons) of response of sorghum to nitrogen and phosphorus were presented in the following four Tables (Tables 4-7).

Table 4. Nitrogen application effect at rates of 0,23, 46, 69 and $92 \mathrm{~kg} \cdot \mathrm{ha}^{-1}$ on sorghum grain and above ground biomass yield (AGB) for OP levels in 6 trials conducted in Ethiopia.

\begin{tabular}{|c|c|c|c|c|c|c|c|c|}
\hline$(2014)(\mathrm{n}=3)$ & $\begin{array}{c}\text { N-Rate } \\
\left(\mathrm{kg} \cdot \mathrm{ha}^{-1}\right)\end{array}$ & 0 & $23 \mathrm{~N}$ & $46 \mathrm{~N}$ & $69 N$ & $92 \mathrm{~N}$ & $\mathrm{~F}<\mathrm{P}$ & CV (\%) \\
\hline GY & \multirow{2}{*}{$\mathrm{Mg} \mathrm{ha}^{-1}$} & $1.79^{c}$ & $2.33^{\mathrm{bc}}$ & $2.56^{\mathrm{a}}$ & $2.43^{\mathrm{ab}}$ & $2.20^{\mathrm{bc}}$ & * & 8.57 \\
\hline AGB & & 7.69 & 7.42 & 7.99 & 7.47 & 7.55 & ns & 13.26 \\
\hline \multicolumn{9}{|l|}{$2015(n=3)$} \\
\hline & \multirow{2}{*}{$\mathrm{Mg} \cdot \mathrm{ha}^{-1}$} & 2.03 & 2.23 & 2.26 & 2.34 & 2.69 & ns & 6.72 \\
\hline AGB & & 7.87 & 8.09 & 7.17 & 7.51 & 7.76 & ns & 14.71 \\
\hline \multicolumn{9}{|l|}{$\begin{array}{l}\text { Site + Season } \\
\quad(n=6)\end{array}$} \\
\hline GY & \multirow{2}{*}{$\mathrm{Mg} \mathrm{ha}^{-1}$} & $1.91^{\mathrm{b}}$ & $2.28^{\mathrm{ab}}$ & $2.41^{\mathrm{ab}}$ & $2.38^{\mathrm{ab}}$ & $2.45^{\mathrm{a}}$ & * & 8.10 \\
\hline AGB & & 7.78 & 7.75 & 7.58 & 7.49 & 7.65 & ns & 13.99 \\
\hline
\end{tabular}

Table 5. Nitrogen application effect at rates of $0,23,46,69$ and $92 \mathrm{~kg} \cdot \mathrm{ha}^{-1}$ on sorghum grain and above ground biomass yield (AGB) @ $20 \mathrm{P} \mathrm{kg} \mathrm{ha}^{-1}$ level in 6 trials conducted in Ethiopia.

\begin{tabular}{|c|c|c|c|c|c|c|c|c|}
\hline $2014(n=3)$ & $\begin{array}{l}\text { N-Rate } \\
\left(\mathrm{kg} \cdot \mathrm{ha}^{-1}\right)\end{array}$ & 0 & $23 N$ & $46 N$ & $69 N$ & $92 \mathrm{~N}$ & $\mathrm{~F}<\mathrm{P}$ & $\mathrm{CV}(\%)$ \\
\hline GY & \multirow{2}{*}{$\mathrm{Mg} \cdot \mathrm{ha}^{-1}$} & 2.38 & 2.39 & 2.39 & 2.47 & 2.54 & ns & 8.57 \\
\hline $\mathrm{AGB}$ & & 6.70 & 7.33 & 7.70 & 8.05 & 6.68 & ns & 13.26 \\
\hline \multicolumn{9}{|l|}{$2015(\mathrm{n}=3)$} \\
\hline GY & \multirow{2}{*}{$\mathrm{Mg} \mathrm{ha}^{-1}$} & 2.42 & 2.15 & 2.31 & 2.41 & 2.33 & ns & 6.72 \\
\hline AGB & & 7.11 & 7.42 & 8.14 & 7.32 & 7.27 & ns & 14.71 \\
\hline \multicolumn{9}{|l|}{$\begin{array}{l}\text { Site + Season } \\
\quad(n=6)\end{array}$} \\
\hline GY & \multirow{2}{*}{$\mathrm{Mg} \cdot \mathrm{ha}^{-1}$} & 2.40 & 2.27 & 2.35 & 2.44 & 2.44 & ns & 8.1 \\
\hline AGB & & 6.90 & 7.38 & 7.92 & 7.68 & 6.98 & ns & 13.99 \\
\hline
\end{tabular}

Table 6. Phosphorus application effect at rates of $0,10,20$ and $30 \mathrm{~kg} \cdot \mathrm{ha}^{-1}$ on sorghum grain and above ground biomass yield (AGB) @ $69 \mathrm{~N} \mathrm{~kg} \mathrm{ha}^{-1}$ level in 3 trials conducted in Ethiopia.

\begin{tabular}{cccccccc}
\hline 2014 (n=3) & ${\mathrm{kg} \cdot \mathrm{ha}^{-1}}$ & OP & 10P & 20P & 30P & F < P & CV (\%) \\
\hline GY & & 2.43 & 2.18 & 2.47 & 2.38 & ns & 8.57 \\
AGB & ${\mathrm{Mg} \cdot \mathrm{ha}^{-1}}$ & 7.47 & 7.96 & 8.05 & 7.87 & $\mathrm{~ns}$ & 13.26 \\
\hline
\end{tabular}


Table 7. Phosphorus application effect at rates of $0,10,20$ and $30 \mathrm{~kg} \cdot \mathrm{ha}^{-1}$ on sorghum grain and above ground biomass yield (AGB) @ $92 \mathrm{~N} \mathrm{~kg} \mathrm{ha}^{-1}$ level in 3 trials conducted in Ethiopia.

\begin{tabular}{cccccccc}
\hline $2015(\mathrm{n}=3)$ & $\mathrm{kg} \cdot \mathrm{ha}^{-1}$ & OP & 10P & 20P & 30P & F < P & CV (\%) \\
\hline GY & & 2.69 & 2.71 & 2.33 & 2.25 & ns & 6.72 \\
AGB & ${\mathrm{Mg} \cdot \mathrm{ha}^{-1}}$ & 7.76 & 7.52 & 7.27 & 7.02 & ns & 14.71 \\
\hline
\end{tabular}

\subsubsection{Grain Yield (GY)}

The mean table of GY showed that sorghum was significantly affected by the application of nitrogen fertilizer alone as compared to the zero control and to each other and hence a maximum yield $2.56 \mathrm{Mg}$ GY obtained by the application of 46 $\mathrm{kg} \mathrm{N} \mathrm{ha}^{-1}$ and has $43 \%$ yield advantage over the control $\left(0 \mathrm{~kg} \mathrm{ha}^{-1}\right)$ at $\mathrm{p}<5 \%$ level. This value also statistically the same as the yield obtained from the treatment received $69 \mathrm{~kg} \mathrm{~N} \mathrm{ha}^{-1}$ (Table 4). This indicated that the application of nitrogen only at lower rate, improved the grain sorghum in 2014 cropping season.

However, in 2015 cropping season the sorghum GY consistently increased

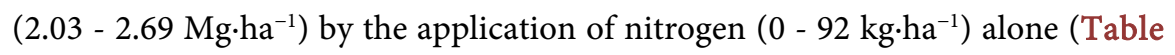
4). These increment of GY were not statistically different from the control at $\mathrm{P}<$ 0.05 level. But, the application of nitrogen alone had 10\% to $32 \%$ yield advantage over the zero control. The combined analysis (sites + seasons) revealed that statistically significant yield differences were observed by the application of highest rate of nitrogen $\left(92 \mathrm{~kg} \cdot \mathrm{ha}^{-1}\right)$ over the control at $\mathrm{P}<0.05$ level. GY of other nitrogen treated plot also greater than the zero control but statistically not different from the zero and to each other. The application of nitrogen had $19 \%-28 \%$ yield advantage over the control. This was due to the soil of Miesso insufficient with total nitrogen (Table 3); thus, the application of nitrogen fertilizer improved the grain yield of sorghum at least by more than $25 \%$ when compared to the zero control. Nitrogen is the main component of most of the vital biomolecules, nucleotides, amino acids, proteins, and hormones related to the plants growth and development [23].

The same rates of nitrogen were also evaluated at $20 \mathrm{~kg} \mathrm{P} \mathrm{ha}^{-1}$ (Table 5). The mean table showed that statistical yield differences or advantages were not observed among the treatments of nitrogen rates in both seasons and combined (sites + seasons) at $\mathrm{p}<0.05$ probability.

The application of 69 or $92 \mathrm{~kg} \cdot \mathrm{ha}^{-1}$ to different rates of $\mathrm{P}\left(0-30 \mathrm{~kg} \cdot \mathrm{ha}^{-1}\right)$ at different seasons (2014 and 2015) showed that there were no statistical yield differences observed among $\mathrm{P}$ rates in the study sites at $\mathrm{P}<0.05$ level. The application of 92 and $69 \mathrm{~kg} \mathrm{~N} \mathrm{ha}^{-1}$ gave the higher GY at $0 \mathrm{P}, 10 \mathrm{P}$ and $0 \mathrm{P}, 20 \mathrm{P}$ than the other $\mathrm{P}$ treated plots respectively (Table 6 and Table 7). This is due to the soil of the study sites adequate in AP content (Table 3).

\subsubsection{Above Ground Biomass (AGB)}

The mean table (Table 4) revealed that AGB were not significantly influenced by 
the treatment factors at $\mathrm{p}<5 \%$ by the application of different rates nitrogen alone. AGB of sorghum in 2014 was $7.99 \mathrm{Mg} \cdot \mathrm{ha}^{-1}$ by the application of $46 \mathrm{~kg} \mathrm{~N}$ $\mathrm{ha}^{-1}$ and $8.09 \mathrm{Mg} \cdot \mathrm{ha}^{-1}$ by the application of small dose $\left(23 \mathrm{~kg} \mathrm{~N} \mathrm{ha}{ }^{-1}\right)$ in 2015 cropping season. Other $\mathrm{N}$ rates in both seasons (2014 and 2015) were lower than the zero control 7.69 and $7.87 \mathrm{Mg} \cdot \mathrm{ha}^{-1}$ respectively. The combined analysis (sites + seasons) revealed than the application of nitrogen at different rates weren't improved AGB yield. The highest AGB yield was observed at the zero control 7.87 $\mathrm{Mg} \cdot \mathrm{ha}^{-1}$.

The application of different rates of nitrogen at $20 \mathrm{~kg} \mathrm{P} \mathrm{ha}^{-1}$ improved AGB by about $20 \%$ by the application of $69 \mathrm{~kg} \mathrm{~N} \mathrm{ha}^{-1}$ in 2014 cropping season, in 2015 and combined (sites + seasons) analysis showed that (Table 5) the application of

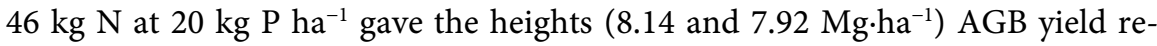
spectively, though statistically not different with other treatments.

In 2014 the application of $69 \mathrm{~kg} \mathrm{~N} \mathrm{ha}^{-1}$ to different rates of $\mathrm{P}$ as shown in $\mathrm{Ta}$ ble 6, not significantly affected AGB at $\mathrm{P}<0.05$ level. The improvement of AGB was not more than $8 \%$ by the application of different rates of $\mathrm{P}$. However, in 2015, the application of $92 \mathrm{~kg} \mathrm{~N}$ to different rates of $\mathrm{P}$ was not different from the yield obtained from the zero control. These may be due to the rain fall pattern during the seasons (Table 1).

\subsection{Nutrient Response Curve}

The effect of nitrogen, and phosphorus fertilizer application rates on the observed grain yield of sorghum during the 2014 season and combined (Sites + Seasons) are presented in Table 4 and Table 5 . The results indicated that the application of $\mathrm{N}$ fertilizer alone significantly $(\mathrm{p} \leq 0.05)$ increased observed sorghum grain yields in the 2014 season and combined (Sites + Seasons). The application of $\mathrm{N}$ with $\mathrm{P}$, however, did not have any significant effect on observed grain yield at $(\mathrm{p} \leq 0.05)$ level. The average observed grain yield for N0 in 2014 season and combined (Sites + seasons) were 1.79 , and $1.91 \mathrm{Mg} \cdot \mathrm{ha}^{-1}$, respectively (Table 4). The response curves were steep increase in sorghum grain yield to $\mathrm{N}$ application alone up to $33 \mathrm{~kg} \cdot \mathrm{ha}^{-1}$ in 2014 season and $61 \mathrm{~N} \mathrm{ha}^{-1}$ combined (sites + seasons), followed by a succeeding yield decline (Table 4). The grain yield of sorghum increased with increasing $\mathrm{N}$ rates till plateau were reached at 33 and 61 $\mathrm{kg} \cdot \mathrm{ha}^{-1} \mathrm{~N}$ application after which the grain yield stabilized (Figure 2) in estimated yields. The increases in observed grain yield with $\mathrm{N}$ application ranged from 0.41 to 0.77 and $0.37-0.54 \mathrm{Mg} \cdot \mathrm{ha}^{-1}$, corresponding to relative increment of $23 \%$ to $43 \%$ and $5.8 \%$ to $16 \%$ over the control in the 2014 season and combined (sites + seasons) respectively. The resulting yield response functions with respect to $\mathrm{N}$ application were as follows:

$$
\begin{gathered}
\text { Yield }=2.39-0.60 \times 0.89^{N}(2014 \text { season }) \\
\text { Yield } \left.=2.43-0.52 \times 0.95^{N} \text { (all sites }+ \text { seasons }\right)
\end{gathered}
$$




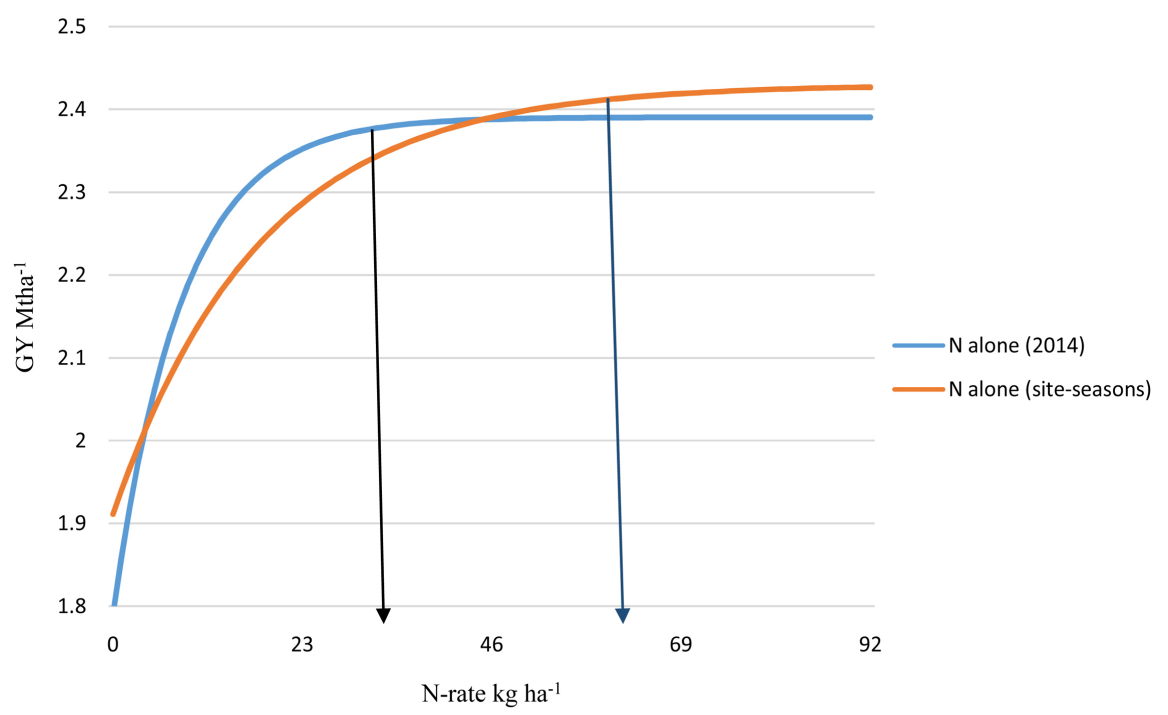

Figure 2. The nutrient response curve of Sorghum as influenced by $\mathrm{N}$ rates alone in 2014 and combined site-seasons at Miesso.

Results of the predicted asymptotic quadratic-plus-plateau yield functions in relation to nutrient rate effects are presented in Table 8. The predicted maximum sorghum grain yields were 2.39 and $2.43 \mathrm{Mg} \cdot \mathrm{ha}^{-1}$ with an average grain yield increase of 0.6 and $0.52 \mathrm{Mg} \cdot \mathrm{ha}^{-1}$ resulting from $\mathrm{N}$ application in 2014 cropping season and combined (sites + seasons) respectively. The expected yield increases for $\mathrm{N}$ following elemental nutrient rate change from 0 to 23,23 to 46,46 to 69 , and 69 to $92 \mathrm{~kg} \mathrm{~N} \mathrm{ha}^{-1}$ were $0.56,0.04,0.002$, and 0.0 , in 2014 season $0.38,0.1$, 0.03 and 0.01 combined (sites + seasons) $\mathrm{Mg} \cdot \mathrm{ha}^{-1}$. The results revealed that yield increased by the application of nitrogen rate change commonly decreases with increasing rates. The nutrient rate change from 46 to $69 \mathrm{~kg} \mathrm{~N} \mathrm{ha}^{-1}$ resulted in an insignificant yield increase of $0.002 \mathrm{Mg} \cdot \mathrm{ha}^{-1}$ whereas a further increment in $\mathrm{N}$ application from 69 to $92 \mathrm{~kg} \mathrm{~N} \mathrm{ha}^{-1}$ did not lead to any yield escalation. In agreement to this study similar occurrence in sub-Saharan Africa were reported by [24] [25] and [26] in maize trials in Kenya, Tanzania and Gahanna respectively.

\subsection{Nutrient Use Efficiency (NUE)}

Agronomic efficiency of nitrogen (AEN) is the amount of increased yield obtained in $\mathrm{kg}$ from addition of a $\mathrm{kg}$ of nutrient [27]. Figure 3 revealed that the highest nitrogen use efficiency was recorded for plots treated with 23 and the lowest treated with $92 \mathrm{~kg} \mathrm{~N}$ ha $^{-1}$ respectively in both 2014 cropping season and combined (site + seasons), the application of lowest dose of $\mathrm{N} 23 \mathrm{~kg}$ (23.48 and $\left.16.09 \mathrm{~kg} \cdot \mathrm{kg}^{-1}\right)$ and the highest dose $92 \mathrm{~kg}\left(4.46-5.87 \mathrm{~kg}\right.$ of sorghum $\mathrm{kg}^{-1}$ ) Figure 3. Therefore, a unit $\mathrm{kg}$ of $\mathrm{N}$ application caused increase in sorghum grain yield by 23.48 and $16.09 \mathrm{~kg}$ from plots treated with $23 \mathrm{~kg} \mathrm{~N} \mathrm{ha}^{-1}$ and 4.46 and $5.87 \mathrm{~kg}$ from plot treated $92 \mathrm{~kg} \mathrm{~N} \mathrm{ha}^{-1}$. In line with this study some scholars reported 
Table 8. Asymptotic nonlinear regression coefficients ( $a, b$, and c) for grain yield in N levels and economically optimal $\mathrm{N}$ rates (EONR) for sorghum with fertilizer $\mathrm{N}$ use cost/grain price ratios $(\mathrm{CP})$.

\begin{tabular}{ccccccccc}
\hline & $\mathrm{a}$ & $\mathrm{b}$ & $\mathrm{c}$ & & $1.2 \mathrm{CP}$ & $1.6 \mathrm{CP}$ & $2.3 \mathrm{CP}$ & $3.6 \mathrm{CP}$ \\
\hline N alone & 2.39 & 0.60 & 0.89 & 2014 & 34 & 32 & 29 & 25 \\
N alone & 2.43 & 0.52 & 0.95 & (Site-Seasons) & 60 & 52 & 45 & 37 \\
& & & & 2014_PCR & 13.13 & 10.41 & 7.81 & 5.40 \\
& & & & (Site-Seasons)_PCR & 5.79 & 4.86 & 3.65 & 2.43 \\
\hline
\end{tabular}

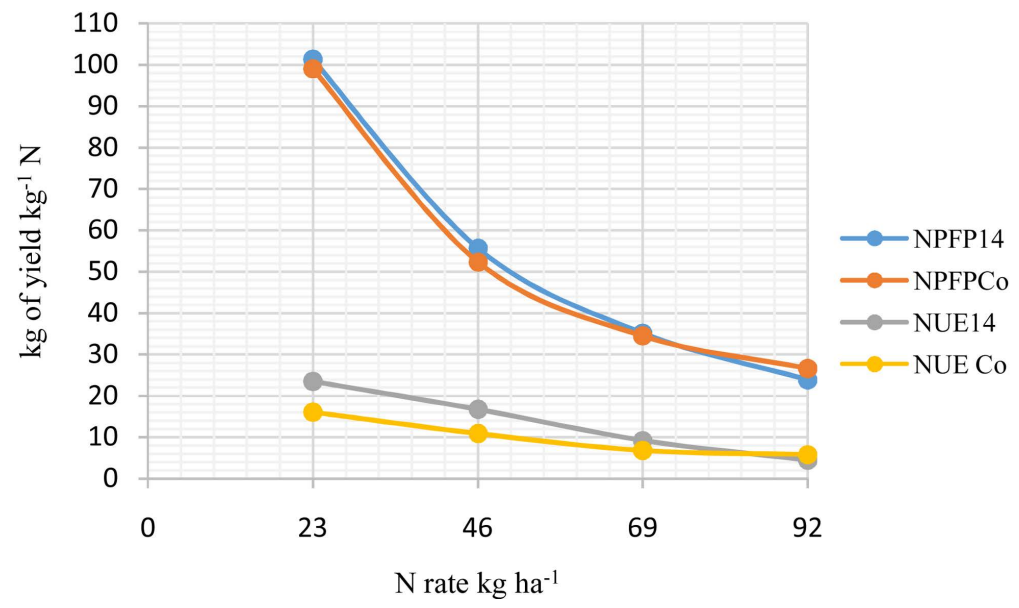

Figure 3. Nutrient use efficiency of sorghum in 2014 cropping season.

that mean agronomic efficiency of $\mathrm{N}$ decreased with increasing $\mathrm{N}$ rate for maize in Uganda [28], wheat in Ethiopia [29].

The PFPN is an aggregate efficiency index that includes contributions to crop yield derived from uptake of indigenous soil $\mathrm{N}, \mathrm{N}$ fertilizer uptake efficiency, and the efficiency with which $\mathrm{N}$ acquired by the plant is converted to grain yield [22]. Figure 3 showed that the highest PFP of $\mathrm{N} \mathrm{101/99} \mathrm{kg}_{\text {grain }} \mathrm{kg}^{-1} \mathrm{~N}$ at the smallest dose $23 \mathrm{~kg} \mathrm{~N}$ and the smallest 23.9/26.6 kg grain $\mathrm{kg}^{-1} \mathrm{~N}$ at the highest dose $92 \mathrm{~kg}$ $\mathrm{N} \mathrm{ha}^{-1}$ in 2014 season/combined (all sites and both seasons). These results are higher than the world average $70 \mathrm{~kg}_{\text {grain }} \mathrm{kg}^{-1} \mathrm{~N}$ as described by [22]. The higher the PFPN may be due to the adequate soil organic carbon pool of the study site (Table 2). Bell [30] and Kolberg [31] described higher indigenous N source from decomposition of the organic $\mathrm{N}$ pools, which can reduce $\mathrm{N}$ fertilizer requirements to maintain yields and thereby increase PFPN.

\subsection{Net Returns to Fertilizer Use}

From the results obtained, the 2014 season and combined (all sites + both seasons) farmers with low financial ability can take benefit of the high earnings (320.09 and 481.01 US $\$ \mathrm{ha}^{-1}$ ) gathered from using low nitrogen application rates 25 and $37 \mathrm{~kg} \cdot \mathrm{ha}^{-1}$ respectively at $\mathrm{CP} 3.75$, (Figure 4) revealed that, the gentler the slope of the response curve, the higher the net returns to nutrient use. 


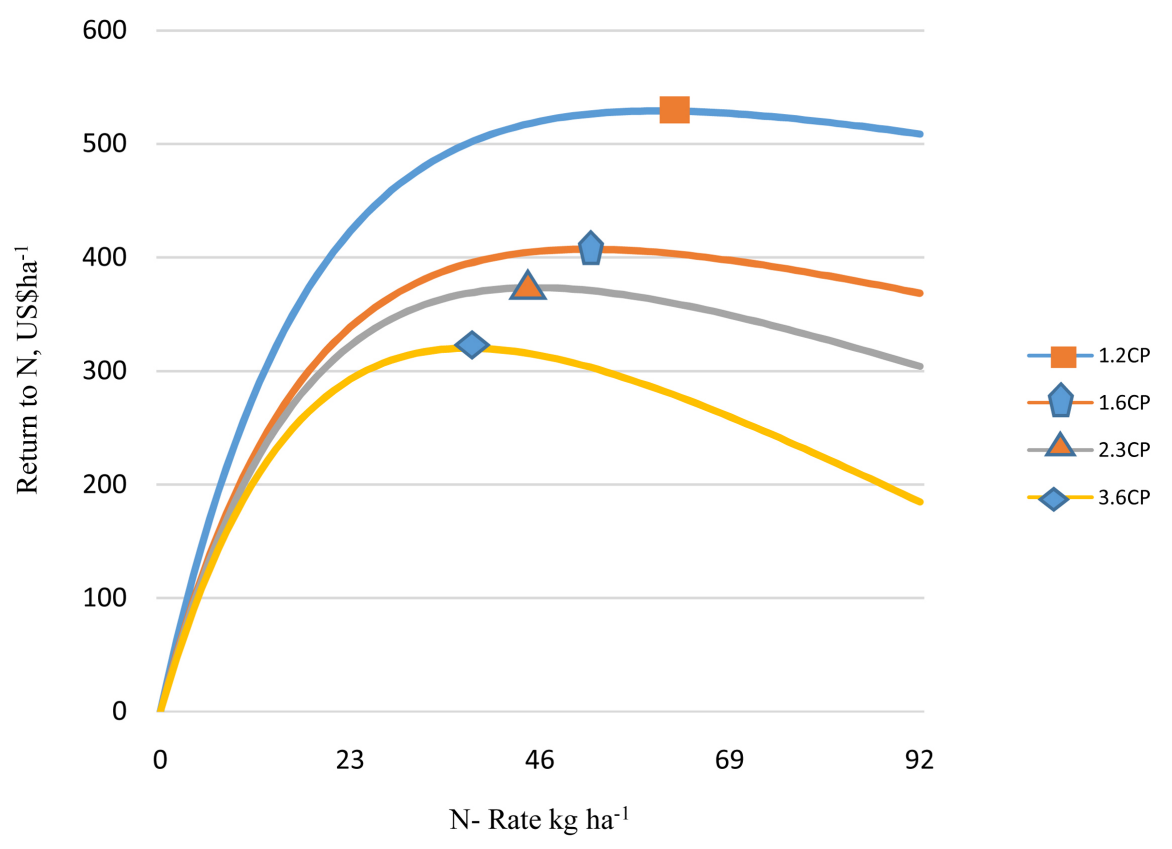

Figure 4. Net returns of sorghum to fertilizer $\mathrm{N}$ application to at varying $\mathrm{N}$ rates and fertilizer cost to grain price ratios (CP) Combined (Sites + seasons). The EONR with each $\mathrm{CP}$ is indicated by a specific symbol at the peak of each curve.

Hence, as the purchasing fertilizer expense increases, the slope decreases until it reaches a plateau and finally drops leading to profit deterioration. In general, the $\mathrm{N}$ application rate exceeded the EONR the net returns to $\mathrm{N}$ fertilizer use diminished. In line with this study, Benedicta [26] reported that in semi-deciduous forest zone of Ghana who recognized that net return and value cost ratio decline as nutrient application rates get further away from the optimum. Different scholars in sub-Saharan Africa have reported higher net returns to fertilizer use. Gittinger [32] reported that a benefit cost (BC) ratio greater than 1 is profitable because the benefits exceed the cost of investment. Net return is dependent on the cost of the nutrient applied and therefore, may vary from place to place. High net returns accounting for high $\mathrm{BC}$ ratios were also reported by [33] Ethiopia.

\subsection{Economically Optimal Nutrient Rates for N Fertilizer Use Cost to Grain Price Ratios}

The EONR in this study combined (site + seasons) were 37, 45, 52 and $60 \mathrm{~kg} \cdot \mathrm{ha}^{-1}$ and for the PCR were 2.43, 3.65, 4.86 and 5.79 for $\mathrm{CP}=3.6,2.3,1.6$ and 1.2 respectively. The semi-arid area is generally characterized by receiving low average annual rainfall less than $500 \mathrm{~mm}$ this caused the crop may have resulted in lower nutrient dissolution and this hindered $\mathrm{N}$ uptake. From the estimated results, net returns of US\$528.89, 407.32, 373.44 and 320.09 for CP 1.2, 1.6, 2.3 and 3.6 could be obtained at the EONR of $60,52,45$ and $37 \mathrm{~kg} \cdot \mathrm{ha}^{-1}$ respectively. Financially constrained smallholder farmers can be benefited at lowest EONR $(37 \mathrm{~kg}$ $\mathrm{N} \mathrm{ha}^{-1}$ ) (Table 7 and Figure 3 ) this was supported by other study with curvili- 
near to plateau responses [34].

Sorghum grain yield were not significantly affected by application of phosphorus for all $\mathrm{N}$ rate at $20 \mathrm{P}$ and for all $\mathrm{P}$ rate at 69 and $92 \mathrm{~kg} \mathrm{~N}$ ha $^{-1}$ thus effect of $\mathrm{P}$ did not fit a response function (Tables 4-6). Liben [35] investigated that application of fertilizer $\mathrm{P}$ in sorghum production is not economically feasible at the Melkassa and Miesso sites.

\section{Conclusion}

Application of different rates of nitrogen and phosphorus treatments was tested at Miesso District West Hararghe zone of Oromia Region, lower doses of nitrogen economically feasible for the sorghum production. AEN and NPFP of also showed the smaller doses gave more intense yield per $\mathrm{kg}$ of nitrogen. This study also revealed application of phosphorus was not economically feasible for sorghum production in this study area. Therefore, at Miesso application of more than $60 \mathrm{~kg} \mathrm{~N} \mathrm{ha}{ }^{-1}$ (EOR) could not be economically important; rather smaller doses improve the PCR and net return. Validation should be farther conducted for EONR on farmers' fields for refining the results obtained from this study.

\section{Acknowledgements}

I would like to thank Fitih Ademe and Eshetu for their technical support to write this article and for the memory of Legesse Teshome for his valuable support when executed this research in managing, harvesting and data handling.

\section{Conflicts of Interest}

The authors declare no conflicts of interest regarding the publication of this paper.

\section{References}

[1] CSA (Central Statistics Agency) (2014) Agricultural Sample Survey 2013/2014 Volume I. Report on Area and Production of Major Crops (Privet Peasant Holdings, Meher Season). Statistical Bulletin 532, Addis Ababa.

[2] Jansen, J.A., Wortmann, C.S., Stockton, M.A. and Kaizzi, C.K. (2013). Maximizing Net Returns to Financially Constrained Fertilizer Use. Agronomy Journal, 105, 573-578. https://doi.org/10.2134/agronj2012.0413

[3] Kaizzi, K.C., Mohammed, B.M. and Nouri, M. (2017) Fertilizer Use Optimization: Principles and Approach. In: Wortmann, C.S. and Sones, K., Eds., Fertilizer Use Optimization in Sub-Saharan Africa, CABI, Wallingford, 9-19. https://doi.org/10.1079/9781786392046.0009

[4] Kaizzi, K.C., Wortmann, C.S. and Jansen, J.A. (2013) More Profitable Fertilizer Use for Poor Farmers. Better Crops, 97, 4-6.

[5] Bouyoucos, G.J. (1962) Hydrometer Method Improved for Making Particle Size Analysis of Soil. Agronomy Jornal, 54, 464-465. https://doi.org/10.2134/agronj1962.00021962005400050028x

[6] Van Reeuwijk, L.P. (1992) Procedures for Soil Analysis. 3rd Edition, International 
Soil Reference and Information Center (ISRIC), Wageningen, $34 \mathrm{p}$.

[7] Walkley, A. and Black, C.A. (1934) An Examination of the Digestive Method for Determining Soil Organic Matter and a Proposed Modification of the Chromic Acid Titration Method. Soil Science, 37, 29-38. https://doi.org/10.1097/00010694-193401000-00003

[8] Bremner, J.M. and Mulvaney, C.S. (1982) Nitrogen-Total. In: Page, A.L., et al., Eds., Methods of Soil Analysis. Part 2. Chemical and Microbiological Properties, SSSA, Madison, 595-642. https://doi.org/10.2134/agronmonogr9.2.2ed.c31

[9] Olsen, S.R., Cole, C.V., Watanabe, F.S. and Dean, L.A. (1954) Estimation of Available Phosphorus in Soils by Extraction with Sodium Carbonate. USDA Circular 939, $1-19$.

[10] Okalebo, J.R., Gathua, K.W. and Womer, P.L. (2002) Laboratory Methods of Sol and Plant Analysis: A Working Manual. 2nd Edition, TSBF-CIAT and SACRED Africa, Nairobi, 128 p.

Papadakis, I.E., Sotiropoulos, T.E. and Therios, I.N. (2007) Mobility of Iron and Manganese within Two Citrus Genotypes after Foliar Application of Iron Sulfate and Manganese Sulfate. Journal of Plant Nutrition, 30, 1385-1396.

https://doi.org/10.1080/01904160701555754

[11] Tan, K.H. (1996) Soil Sampling, Preparation, and Analysis. Marcel Dekker, Inc., New York.

[12] FAO (Food and Agriculture Organization) (2006) Plant Nutrition for Food Security: A Guide for Integrated Nutrient Management. FAO, Fertilizer and Plant Nutrition Bulletin 16, Rome.

[13] Jones, J.B. (2003) Agronomic Handbook: Management of Crops, Soils, and Their Fertility. CRC Press LLC, Boca Raton, 482 p.

https://doi.org/10.1201/9781420041507

[14] Clements, B. and McGowen, I. (1994) Strategic Fertilizer Use on Pastures. NSW Agriculture. Agnote Reg. 4/57, Orange, NSW.

[15] Bruce, R.C. and Rayment, G.E. (1982) Analytical Methods and Interpretations Used by the Agricultural Chemistry Branch for Soil and Land Use Surveys. Queensland Department of Primary Industries. Bulletin QB8 (2004), Indooroopilly.

[16] Tadese, T. (1991) Soil, Plant, Water, Fertilizer, Animal Manure and Compost Analysis. Working Document No. 13, International Livestock Research Center for Africa, Addis Ababa.

[17] Hazelton, P. and Murphy, B. (2007) Interpreting Soil Test Results: What Do All the Numbers Mean? 2nd Edition, CSIRO Publishing, Clayton, 152 p. https://doi.org/10.1071/9780643094680

[18] Landon, J.R. (2014) Booker Tropical Soil Manual: A Handbook for Soil Survey and Agricultural Land Evaluation in the Tropics and Subtropics. Routledge, London, 530. https://doi.org/10.4324/9781315846842

[19] SAS (2002) Statistical Analysis System: Version 9.0. SAS Institute Inc., Cary.

[20] Gomez, K.A. and Gomez, A.A. (1984) Statistical Procedures for Agricultural Research. Second Edition, John Wiley \& Sons, Inc., Hoboken.

[21] Snyder, C.S. and Bruulsema, T.W. (2007) Nutrient Use Efficiency and Effectiveness in North America. Indices of Agronomic and Environmental Benefits. IPNI Publication Ref. \# 07076, International Plant Nutrient Institute, Norcross.

[22] Dobermann and Achim, R. (2005) Nitrogen Use Efficiency-State of the Art. 
Agronomy \& Horticulture-Faculty Publications. 316. https://digitalcommons.unl.edu/agronomyfacpub/316

[23] Frink, C.R., Waggoner, P.E. and Ausubel, J.H. (1999) Nitrogen Fertilizer: Retrospect and Prospect. Proceedings of the National Academy of Sciences of the United States of America, 96, 1175-1180. https://doi.org/10.1073/pnas.96.4.1175

[24] Kibunja, C.N., Ndungu-Magiroi, K.W., Wamae, D.X., Mwangi, T.J., Nafuma, K., Koech, M.N., Ademba, J. and Kitonyo, E.M. (2017) Optimizing Fertilizer Use within the Context of Integrated Soil Fertility Management in Kenya. In: Wortmann, C.S. and Sones, K., Eds., Fertilizer Use Optimization in Sub-Saharan Africa, CAB International, Nairobi, 82-99. https://doi.org/10.1079/9781786392046.0082

[25] Senkoro, C.J., Ley, G.J., Marandu, A.E., Wortmann, C., Mzimbin, M., Msaky, J., Umbwe, R. and Lyimo, S.D. (2017) Optimizing Fertilizer Use within the Context of Integrated Soil Fertility Management in Tanzania. In: Wortmann, C.S. and Sones, K., Eds., Fertilizer Use Optimization in Sub-Saharan Africa, CAB International, Nairobi, 176-192. https://doi.org/10.1079/9781786392046.0176

[26] Benedicta, E., Robert, C.A., Andrews, O. and Nana, E.M. (2020) Economically Optimal Rate for Nutrient Application to Maize in the Semi-Deciduous Forest Zone of Ghana. Journal of Soil Science and Plant Nutrition, 20, 1703-1713. https://doi.org/10.1007/s42729-020-00240-y

[27] Fageria, N.K. and Baligar, V.C. (2001) Lowland Rice Response to Nitrogen Fertilization. Communication Soil Science and Plant Analysis, 32, 1405-1429. https://doi.org/10.1081/CSS-100104202

[28] Kaizzi, K.C., Byalebeka, J., Semalulu, O., Alou, I., Zimwanguyizza, W., Nansamba, A., Musinguzi, P., Ebanyat, P., Hyuha, T. and Wortmann, C.S. (2012) Maize Response to Fertilizer and Nitrogen Use Efficiency in Uganda. Agronomy Journal, 104, 73-82. https://doi.org/10.2134/agronj2011.0181

[29] Tarekegne, A. and Tanner, D.R. (2001) Effects of Fertilizer Application on N and P Uptake, Recovery and Use Efficiency of Bread Wheat Grown on Two Soil Types in Central Ethiopia. Ethiopian Journal of Natural Resources, 3, 219-244.

[30] Bell, M.A. (1993) Organic Matter, Soil Properties, and Wheat Production in the High Valley of Mexico. Soil Science, 156, 86-93.

https://doi.org/10.1097/00010694-199308000-00004

[31] Kolberg, R.L., Westfall, D.G. and Peterson, G.A. (1999) Influence of Cropping Intensity and Nitrogen Fertilizer Rates on in Situ Nitrogen Mineralization. Soil Science Society of America Journal, 63, 129-134. https://doi.org/10.2136/sssaj1999.03615995006300010019x

[32] Gittinger, J.P. (1982) Economic Analysis of Agricultural Projects. 2nd Edition, John Hopkins University Press, Baltimore, 526.

[33] Negash, D. and Bekele, I. (2017) Optimizing Fertilizer Use within the Context of Integrated Soil Fertility Management in Ethiopia. In: Wortmann, C.S. and Sones, K., Eds., Fertilizer Use Optimization in Sub-Saharan Africa, CAB International, Nairobi, 52-66. https://doi.org/10.1079/9781786392046.0052

[34] Wortmann, C.S. (2018) Geo-Referenced Crop-Nutrient Response Function Dataset for Tropical Africa. Data from: Maize Nutrient Response Information Applied across Sub-Saharan Africa.

[35] Liben, F.M., Adisu, T., Atnafu, O., Bekele, I., Berhe, H. and Wortmann, C.S. (2020) Maize and Sorghum Nutrient Response Functions for Ethiopia. Nutrient Cycling in Agroecosystems, 117, 401-410. https://doi.org/10.1007/s10705-020-10077-7 